\title{
Influence of Innovation on The Performance of Commercial Banks in Nakuru Central Business District
}

\author{
Judith Kemunto Oira*, \& Dr Patrick Kibati** \\ *Master of Business Administration (Finance) at Jomo Kenyatta University of Agriculture and Technology, \\ Nakuru Campus, Kenya. \\ **Lecturer at Jomo Kenyatta University of Agriculture and Technology, Kenya.
}

\begin{abstract}
Kenyan commercial banks have continued to use huge investments in innovations and Training of manpower to handle new technologies. The fast-changing competitive environment, globalization, economic changes, regulation, privatization and the like demands that commercial banks are run efficiently and effectively by continuously engaging in innovations. The relationship between the growing investment in bank innovations and bank financial performance in Kenya needs to be studied. If an organization is not capable of introducing innovations on an ongoing basis, it risks that it will lag behind and the initiative will be taken over by other entities. The main objective of the study was to establish the effect of financial innovations on financial performance of commercial banks in Kenya. The specific objectives of the study were to; find out the impact of mobile technology on financial performance of commercial banks, to examine the effect of agent banking on financial performance of commercial banks, to find out the effect of internet banking on financial performance of commercial banks and to investigate the effects of banc assurance on financial performance of commercial banks in Kenya. Population of study comprised of 45 commercial banks employees from 9 banks that use mobile banking, agent banking, internet banking and banc assurance in Nakuru. These banks are Cooperative bank, Kenya Commercial bank, Equity bank, Family bank, Chase bank, National Bank of Kenya, NIC bank, consolidated bank and DTB. Primary data was obtained through questionnaires which was carried out in commercial banks in Nakuru town and was evaluated using explanatory research design while a questionnaire was used to gather primary data. Secondary data was obtained from Central Bank of Kenya and banking survey manuals. The research adopted census technique where every element in the population was included; hence the population was 45. The analysis of the quantitative data was done using statistical package of social science (SPSS) software version 21. Multiple regression analysis was used to test the relationship between bank innovations and financial performance among commercial banks in Kenya. In addition, the Pearson Product Moment Correlation Coefficient was used to test the direction and magnitude of the relationship between the dependent and independent variables.
\end{abstract}

Keywords: Performance, Innovation

\section{Introduction}

Innovation has been an integral component of economic activity for several millennia (Goetzmann, 2009). The Kenyan financial sector has undergone tremendous changes in the last two decades. A lot of reforms have been undertaken in the sector that have led to proliferation of financial products, activities and organizational forms that have improved and increased the efficiency of the financial system. Advances in technology and changing economic conditions have created impetus for this change. All these developments coupled with changes in the international financial environment and the increasing integration of domestic and international financial markets have led to rapid financial innovation. The rising importance of the financial sector in modern economies, as well as the rapid rate of innovation in that sector, has generated a research interest in innovation.

Different scholars have done studies on electronic and mobile banking in Kenya. Jonathan and Camillo, (2008) studied the impact of mobile banking and technology on transaction costs of microfinance institutions where he found out that by then, innovation had reduced transaction costs considerably though they were not directly felt by the banks because of the then small customer base. The current study differs from Jonathan and Camillo (2008), because the rate of innovation and the number of banks which have adopted innovation have increased.

Aduda and Kingoo (2012) did a study on the relationship between electronic banking and financial performance of commercial banks in Kenya where he paid keen attention on the microfinance institutions in Nairobi. He found out that there exists a strong positive relationship between electronic banking and bank performance in respect to return on assets. However, Aduda and Kingoo (2012) looked at the wider electronic banking whereas this study will concentrate on innovation and not electronic banking. 
Abishua, (2010) studied the application of mobile banking as a strategic response by Equity Bank Kenya limited to the challenge in the external environment. He reviewed the concept of mobile banking as a strategic response where its effects on competitive advantages were not considered.

In India, Pooja and Singh (2009) conclude that innovative banks were larger, more profitable, had higher competitive advantage, lower administrative expenses and were more efficient compared to the noninnovative banks. In Jordan, internet banking resulted to more satisfied customers and better long-term cost saving strategies hence increased competitive advantage (Siam, 2006). Closer home, Gardachew (2010) document that Ethiopian banks have not been able to achieve efficiency as a result of slow adaptation of technological innovations. In a study on the banking sectors of 11 Latin American countries, Yildirim and Philippatos (2007) stipulate that rivalry between banks pushes the banks to engage in a differentiation processes of the products they supply, and can stimulate innovation.

In Uganda, adoption of electronic and mobile banking has increased access to banking services leading to a wide customer base (Porteus, 2006). In Ghana over time, technology has increased in importance in Ghanaian banks and has transformed the way banks would serve their clients more conveniently and in the process increase profits and competitiveness while the most revolutionary electronic innovation in Ghana and the world over has been the ATM (Joshua, 2010). In Nigeria, internet banking has resulted to improved e-Commerce and e-Payment services with overall reduction in the amount of currency in circulation. From the above discussions, it is evident that not much research has been done on innovation and its effects on financial performance of commercial banks. This research therefore aims at bridging the gap. The study therefore seeks to address the knowledge gap on how innovation leads to financial performance of commercial banks in Kenya. It will identify the connection between innovation and financial performance in the banking sector and its implications.

Commercial banks are profit making financial institutions that play a significant role in the financial system. Commercial banks offer a wide range of corporate financial services that address the specific needs of private enterprise. They provide deposit, loan and trading facilities but will not service investment activities in financial markets (Magutu., 2009). The CBK, which falls under the Minister for Finance's docket, is responsible for formulating and implementing monetary policy and fostering the liquidity, solvency and proper functioning of the financial system. The CBK publishes information on Kenya's commercial banks and nonbanking financial institutions, interest rates and other publications and guidelines. The banks have come together under the Kenya Bankers Association (KBA), which serves as a lobby for the banks' interests and addresses issues affecting its members (Kenya Bankers Association annual Report, 2008).

Commercial banks in Kenya play a number of roles in the financial stability and cash flow of the country's private sector. They process payments through a variety of means including telegraphic transfer, internet banking and electronic funds transfers. They also issue bank cheques and drafts, as well as accept money on term deposits. They act as moneylenders, by way of installment loans and overdrafts. Loan options include secured loans, unsecured loans and mortgage loans. Commercial banks in Kenya provide a number of import financial and trading documents such as banks is predominated by financial assets and liabilities hence giving rise to an emphasis on the net interest margin. Interest rate environment is one of the most important influences on asset/liability decisions of commercial banks.

Previous studies like that of Pooja and Singh (2009), Franscesa and Claeys (2010), Batiz-Lazo and Woldesenbet (2006) and Mwania and Muganda(2011) have produced mixed results regarding the impact of financial innovations on bank performance. Pooja and Singh (2009), and Franscesa and Claeys (2010) , in their studies concluded that financial innovations had least impact on bank performance, while Batiz-Lazo and Woldesenbet (2006) concluded that financial innovation had significant contribution to bank performance. It is at the center of such mixed conclusions that created and necessitated the need to carry out a study from a Kenyan context to establish the effect of bank innovations on commercial banks' performance. Impact on bank's financial performance remains lowly untested.

Kenyan commercial banks have continued to deploy huge investments in technology based innovations and training of manpower to handle the new technologies. Although studies have been carried out on the contribution of financial innovation to the effectiveness of the monetary policy; few studies have sought to relate financial innovation to financial performance in the banking sector. Mwangi, focused on the effects of bank innovations on financial performance of commercial banks in Kenya. The study focused on effects of bank innovations on income of banks, return of assets, bank profitability and customer deposits. In addition, the study only focused on mobile phone banking, ATM banking and online banking but failed to look at agency banking and banc assurance which is a key component of the bank innovations today. 


\section{Theoretical Review}

\section{Literature Review}

The study is based on the Task technology fit model (TTF). TTF was developed by Dishaw and Strong, (1999). This theory contends that it is more likely to have a positive impact on individual performance and be used if the capabilities of Information Communication and Technology (ICT) matches the tasks that the user must perform. Good hue and Thompson (1995) mention the factors that measure task-technology fit as; quality, authorization, and compatibility, eases of use/training, production timeliness, systems reliability and relationship with users. The model is useful in the analysis of various context of a diverse range of information systems including electronic commerce systems and combined with or used as an extension of other models related to information systems outcomes. According to the theory of tasktechnology fit, the success of an information system should be related to the fit between task and technology, whereby success has been related to individual performance and to group performance (Zigurs \& Buckland, 1998). For group support systems, a specific theory of task-technology fit was developed and later tested by Zigurs, Buckland, Connolly and Wilson, (1999) and detailed the requirements of group support systems to fit group tasks. For mobile information systems, task-technology fit has been shown to be generally relevant, but more specific questions regarding the applicability of task-technology fit to mobile information systems remain unanswered.

This model is consistence with one proposed by, Delone and Mclelan. (1992) in that both utilization and users attitude about technology leads to individual performance impact. It goes beyond Delon and Mclean model in two important ways. First it highlights the importance of task technology fit in explaining how technology leads to performance impacts, second it is more explicit concerning the link between the construct providing stronger theoretical basis for thinking about a number of issues relating to the impact of Information technology and performance.

The theory of task-technology fit maintains that a match between business tasks and information technology is important to explain and predict the success of information. For various scenarios of task and technology, statistical significance has been established of a positive association between task-technology fit and information system success measures, such as use and impact on individual performance.

The concept of task-technology fit promises to help identify aspects that are critical to support a given business task, and can, thus, contribute to the success of technology innovations (Junglas \& Watson, 2006). One such innovation is represented by mobile technology to support an increasingly mobile workforce (Barnes, 2003). Upon applying the theory of task-technology fit to mobile information systems, however, it becomes apparent that previous studies have focused mainly on the functionality that is provided by the technology, and have paid less attention to the context in which the technology is being used at the same time, however, usability studies suggest that the use-context may have a non-trivial impact on the conditions of task-technology fit (Perry., 2001). First, it can be observed that nonfunctional features, such as weight and size, play a more prominent role in mobile than in non-mobile use contexts second, functional requirements may shift as business tasks are often performed differently in mobile versus non-mobile use contexts.

This theory is relevant in the sense that as a result of the observable changes of business tasks and related technology requirements, it becomes necessary to assess the applicability of the theory of tasktechnology fit to mobile technologies and mobile use contexts, and to carefully determine the needs for theory adjustments and extensions. It analyses how mobile banking contributes to competitive advantage of commercial banks in Kenya.

\section{Mobile Banking and Financial Performance of Commercial Banks .}

Encouraging customers to use innovation such as the mobile telephones for banking transactions can result in considerable operating costs savings (Sathye, 1999). Simpson, (2002) Suggests that m-banking is driven largely by the prospects of operating under minimum costs and operating increasing revenues maximization. A comparison of online banking in developed and emerging markets revealed that in developed markets lower costs and higher revenues are more noticeable (Ngumi, 2013). M-banking and internet banking are cost effective ways to provide banking services to the unbanked because there is no need to set up physical branches to facilitate customers it is called as it is 'branchless banking'. Its branchless bank model includes enhanced ability to carry out limited banking transactions via mobile phone.

Connectivity for mobile device is not the part of banking service it is duly and part of business of telecommunication department and cellular service providers. Hence, banks should only lease the telecommunication lines provided by telecommunication department to provide access to the financial services. The terms m-banking, m-payments, $\mathrm{m}$ - transfers and $\mathrm{m}$-finance refer collectively to a set of applications that enable people to use their mobile telephones to manipulate their bank accounts, store value in an account linked 
to their handsets, transfer funds, m-banking or even access credit or insurance products. The first targets for these applications were consumers in the developed world. By complementing services offered by the banking system, such as check books, ATMs, voicemail/landline interfaces, smart cards, point of sale networks and internet resources, the mobile platform offers a convenient additional method for managing money without handling cash (Karjaluoto, 2002).

Though the M- banking idea was initially born out of the intention to reach the unbanked poor, (Porteous, 2006). It has stretched its tentacles far and wide to captivate the interest of unimagined client segments. Even the prudential banks have joined the fray and are now acting as agents and outlets of Mobile service provider banking services. This could have come as a realization on the part of the traditional banks of the maxim that "if you can't beat them; join them." Cash transactions, account opening and other transactions can be conducted online. Ultimately transformational banking boosts access to formal finance particularly, in rural areas where many poor people live.

Mobile phone operators have identified m-banking / m-payments systems as a potential service to offer customers, increasing loyalty while generating fees and messaging charges. There is no universal form of $\mathrm{m}$ banking, rather, purpose and structures vary from country to country. The systems offer a variety of financial functions, including micropayments to merchants, bill payments to utilities, transfers between individuals and long distance remittances. Currently, different institutional and business models deliver these systems. Some are offered entirely by banks, others entirely by telecommunications providers and still others involve a partnership between a bank and telecommunications provider (Porteuos, 2006).

The new services offer a way to move money from place to place and present an alternative to the payment systems offered by bank, remittance firms and pawn shops. The uptake of m-banking / m-payments systems has been particularly strong in the Phillipines, where three million customers use systems offered by mobile operators Smart and Globe in South Africa, where 450,000 people use Wiz it ("the bank in your pocket") (Ivatury \& Pickens, 2006) or one of two other national systems (Porteous, 2007); and in Kenya, where nearly two million users registered with Safaricom M-Pesa system within a year of its nationwide rollout (Ivatury \& Picken, 2006; Vaughan, 2007).

\section{Agent Banking and Financial Performance of Commercial Banks}

Banking through retail agents is a concept that is beginning to appeal to policy makers and regulators. It has the potential to extend financial services to unbanked and marginalized communities. Agent - assisted banking is a relatively new concept. What makes agent banking work are information and communication technologies which customers, retail agents and banks use to record and communicate transaction details quickly, reliably and cheaply over vast distances. For example even in rural areas many poor people have access to low cost mobile phones and prepaid airtime dealers. For banks agent banking is used to reduce the cost of delivering financial services, relieve crowds in bank branches and establish presence in new areas. (Kumar et al .2006).

According to Chaia, (2011) agent banking has become one of the most promising strategies for offering financial services in emerging markets. In this model, financial institutions work with networks of existing nonbank retail outlets such as convenience stores, gas stations, and post offices to deliver financial services. This approach can be especially powerful when serving the unbanked poor because of its ability to reduce banks costs and reach low income workers where they live. Agent banking benefits arrange of stakeholders. The poor gain convenient access to financial services in their own communities. Financial institutions reach a vast new customer segment. Agents increase their sales volumes and have an opportunity to develop deeper relationships with the customer. However implementing correspondent strategies can be tough. It may be hard to build networks of partners that can fulfil the correspondent role. The economics are still uncertain for players that do not offer a range of services. And because the strategy is relatively new for financial service providers, it is difficult to know exactly what will work in each particular community.

According to Veniard, Bill and Gates Foundation, (2010) how agent banking changes the economics of small accounts " one of the primary impediments to providing financial services to the poor through branches and other bank based delivery channels is the high cost inherent in these traditional banking methods. The amount of money expended by financial service providers to serve a poor customer with a small balance and conducting small transactions is simply too great to make such accounts viable. In addition when financial service providers do not have branches that are close to the customer, the customer is less likely to use and transact with their services. Customer dissatisfaction with branch banking because of long queuing and poor customer service is an important reason for the rapid movement to electronic delivery (Karjaluoto, 2002). Internet offers a potential competitive advantage for banks and this advantage lies in the areas of cost reduction and more satisfaction of customer needs (Bradley, 2003). The commitment of senior management is a driving force in the adoption and exploitation of technology (Shiels, 2003). 
(Agboola, 2006) in his study on Information and Communication Technology (ICT) in Banking operations in Nigeria using the nature and degree of adoption of innovative technologies; degree of utilization of the identified technologies; and the impact of the adoption of ICT devices on banks, found out that technology was the main driving force of competition in the banking industry. During his study he witnessed increase in the adoption of agent banking. He indicates that adoption of ICT improves the banks' image and leads to a wider, faster and more efficient market. He asserts that it is imperative for bank management to intensify investment in ICT products to facilitate speed, convenience, and accurate services, or otherwise lose out to their competitors.

\section{Internet Banking and Financial Performance of Commercial Banks}

Internet banking refers to the use of the internet as a delivery channel for banking services, which includes all traditional services such as balance enquiry, printing statement, fund transfer to other accounts, bills payment and new banking services such as electronic bill presentment and payment (Frust, Lang, \& Nolle, 2000), without visiting a bank (Mukherjee \& Nath, 2003). The rapid growth and popularity of the internet has created great opportunities as well as threats to companies in various business sectors, to endorse and deliver their products and services using internet as a distribution channel (Chau \& Lai, 2003). Beside opportunities of this channel, banks and financial institutions across the world face new challenges to the ways they operate, deliver services and compete with each other in the financial sector. Driven by these challenges, banks and financial institutions have implemented services delivery using internet banking (Chan \& Lu, 2004). The objectives of launching internet banking include cost reduction, performance improvement, wider coverage, revenue growth, and customer convenience

From the customer's perspective, internet banking facilitates a convenient and effective approach to manage personal finances, as it is accessible 24 hours a day and 365 days in a year without visiting the bank and from many locations. (Bradley \& Stewart, 2002; Chau \& Lai, 2003). Nyangosi, (2011) argue that financial institutions adopted different electronic distribution channels to meet the demands of customers thus improving customer satisfaction. In their study to examine the adoption of information technology in Kenyan banks focusing on services provided through internet banking, they found out that inclusion of information technology in banking business was necessary to achieve excellence goal of customer satisfaction. They also found out that customers use bank websites to know the products, use mobile banking to check balance, know after sale services and buy products, writing checks, paying bills, transferring funds, printing statements and checking account balances online using a computer (Acharya, 2009) an indication that mobile banking is gaining popularity and becoming vital in financial transaction events. Today, information and communication technology has become the heart of banking sector, while banking industry is the heart of every robust economy (Ngumi, 2013).

\section{Banc Assurance and Financial Performance of Commercial Banks}

Jongeneel (2011) did a paper on Banc assurance: APan-European country analysis. In his study, the researcher sought to identify the critical driver s in Banc assurance as a distribution channel for insurers. A global comparison of Banc assurance was given through different business models and a descriptive design extended by an analysis of previous literature. Subsequently, a quantitative country-level assessment was performed. The researcher used examined factors such as market concentration, internet usage, and size of insurance market, level of deregulation and bank's branch density to measure their impact on the proportional size of banc assurance. The empirical results indicated that all the five variables affected Banc assurance although the size of the insurable market only held for nonlife sample.

Omondi, (2013) did a study on the determinants of adoption of banc assurance by Commercial Banks in Kenya. The target population was drawn from the Forty- three licensed commercial banks comprising of six large banks, fifteen medium sized and twenty-two small banks. The results of the study showed that adoption of banc assurance by Commercial Banks was influenced by the need for new revenue stream, diversification and economies of scope. There was a significant positive relationship between need for new revenue stream, business diversification, economies of scope and adoption of banc assurance by Commercial Banks.

Nyakundi, (2013) did a study on Management Perception of banc assurance as Risk Mitigation Strategy at Equity Bank Limited. The purpose of the study was to establish if Equity Bank and Insurance Companies can mitigate some of the management problems such as high loan default leading to high credit risks, switching of customers due to dissatisfaction, declining profits, resistance to buy new insurance products hence minimum growth. 
The specific objectives of the study included;

\section{Objective of the Study}

i. To investigate the effects of mobile banking on financial performance of commercial banks in Kenya.

ii. To establish the effects of agent banking on financial performance of commercial banks in Kenya.

iii. To find out the effects of internet banking on financial performance of commercial banks in Kenya.

iv. To investigate the effects of banc assurance on financial performance of commercial banks in Kenya.

\section{Research Hypotheses}

This study sought to address the following pertinent research hypotheses;

Ho: $_{1}$ : Mobile banking has no significant influence on financial performance of commercial banks in Kenya.

$\mathbf{H 1}_{1}$ : Mobile banking has significant influence on financial performance of commercial banks in Kenya.

$\mathbf{H o}_{2}$ : Agent banking has no significant influence on financial performance of commercial banks in Kenya.

$\mathbf{H I}_{2}$ : Agent banking has significant influence on financial performance of commercial banks in Kenya.

$\mathbf{H o}_{3}$ : Internet banking has no significant influence on financial performance of commercial banks in Kenya

$\mathbf{H l}_{3}$ : Internet banking has significant influence on financial performance of commercial banks in Kenya.

$\mathbf{H o}_{4}$ : Banc assurance has no significant influence on financial performance of commercial banks in Kenya.

$\mathbf{H l}_{4}$ : Banc assurance has significant influence on financial performance of commercial banks in Kenya.

\section{Methodology}

Research design is the structuring of investigation aimed at identifying variables and their relationship to one another. The researcher will use explanatory research design. This is concerned with determining the causal link between variables that pertain to the research (Churchill, 1991). Population in statistics is the specific population about which information is desired. According to Ngechu (2004), a population is a well-defined or set of people, services, elements, events, group of things or households that are being investigated. An element is the subject on which the measurement is being taken and is the unit of the study. This was a study of five employees from nine commercial banks in Nakuru town that uniformly employ mobile banking, agent banking, internet banking and banc assurance. This formed a population of 45 employees. The respondents included the overall manager, bank officer responsible for mobile banking, officer responsible for agent banking, officer responsible for internet banking and bank officer responsible for banc assurance; hence the five employees from each of the nine commercial banks induced a sample size of 45 . The study employed census sampling technique. A census sample is the study of every unit in a population, and it occurs if the entire population is very small or it's reasonable to include the entire population. The size of 45 bank employees is relatively small and therefore deemed appropriate to collect data from Central Business District in Nakuru hence easily accessible. Out of 45 distributed questionnaires, 41 were answered well and returned. This was equivalent to $91.1 \%$.

Mobile Banking

\section{Findings and Discussions}

Table 1: Response by employees as to whether mobile banking influences financial performance

\begin{tabular}{|c|c|c|c|c|c|c|c|}
\hline Statements & 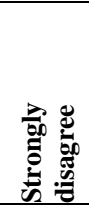 & 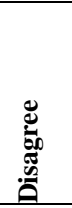 & 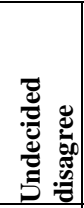 & 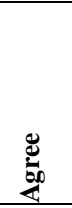 & 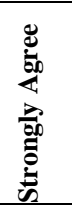 & $\sum_{\tilde{\Sigma}}^{\tilde{E}}$ & $\begin{array}{l}\vec{\Delta} \\
\text { Dे } \\
\text { is }\end{array}$ \\
\hline $\begin{array}{l}\text { Mobile banking help us focus on customer loyalty } \\
\text { program }\end{array}$ & 0 & 12.5 & 0 & 46.3 & 41.5 & 1.83 & 0.95 \\
\hline $\begin{array}{l}\text { Mobile banking enables us to employ up selling } \\
\text { strategies for lifetime value customer }\end{array}$ & 0 & 9.8 & 2.4 & 48.5 & 39 & 1.83 & 0.89 \\
\hline Mobile banking is able to offer a variety of services & 2.4 & 4.9 & 0 & 41.5 & 51.6 & 1.66 & 0.91 \\
\hline $\begin{array}{l}\text { Mobile banking is effective in developing long term } \\
\text { customer relationship }\end{array}$ & 2.4 & 9.8 & 0 & 48.8 & 29.3 & 2.07 & 1.0 \\
\hline $\begin{array}{l}\text { Collected data from mobile banking is used in } \\
\text { planning new customer acquisition strategies }\end{array}$ & 7.3 & 17.1 & 12.2 & 39 & 24.4 & 2.44 & 1.24 \\
\hline
\end{tabular}

From the results depicted in Table 1, majority of the respondents agreed that Mobile banking is effective in developing long term customer relationship, as shown by a mean score of 2.07, collected data from mobile banking is used in planning new customer acquisition strategy the best as shown by a mean score of 2.44, Mobile banking enables us to employ up selling strategies for lifetime value customer as shown by a mean score of 1.83, Mobile banking help us focus on customer loyalty program as shown by a mean score of 1.83 and Mobile banking is able to offer a variety of services as shown by a mean score of 1.66. 


\section{Agent Banking}

Table 2: Response of the Employees on Agent Banking

\begin{tabular}{|c|c|c|c|c|c|c|c|}
\hline Statement & 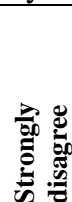 & 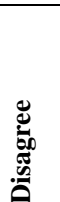 & 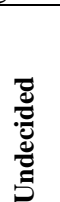 & 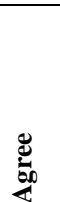 & 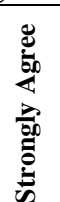 & $\sum_{\Sigma}^{\tilde{E}}$ & 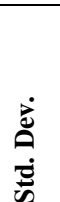 \\
\hline Agent banking increases number of bank transactions & 2.4 & 12.2 & 2.4 & 19.5 & 63.4 & 1.71 & 1.15 \\
\hline Agent banking has minimised fraud cases & 0 & 36.6 & 9.8 & 19.5 & 34.1 & 2.49 & 1.31 \\
\hline Agent banking has led to banks geographical expansion & 12.4 & 0 & 7.3 & 31.7 & 58.5 & 1.96 & 0.84 \\
\hline Agent banking has led to decongestion of branches & 4.9 & 14.6 & 7.3 & 51.2 & 22 & 2.29 & 1.12 \\
\hline Agent banking has minimised banks operational costs & 0 & 0 & 19.8 & 26.8 & 53.7 & 1.85 & 1.15 \\
\hline
\end{tabular}

Table 2 shows the percentage of respondents and their views on how Agent banking influence financial performance among Kenyan commercial banks. Agent banking increases number of bank transactions as agreed by $63.4 \%$ of the respondents. Agent banking has led to banks geographical expansion as greed by 58.5\%. 34.1 $\%$ of the respondents strongly agreed that agent banking has minimised fraud cases, $51.2 \%$ agree that agent banking has led to decongestion of branches, and $53.7 \%$ agree that agent banking has minimised operation costs. The mean score for the responses was 2.1 indicating more agreement that mobile banking influences financial performance mobilization among commercial banks in Kenya.

\section{Internet Banking and Financial Performance}

Table 3: Response of the Employees on Internet Banking

\begin{tabular}{|c|c|c|c|c|c|c|c|}
\hline Statement & 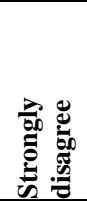 & 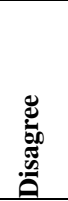 & 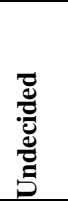 & 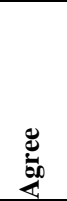 & 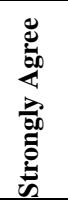 & 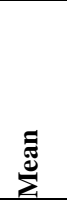 & $\begin{array}{l}\dot{\Xi} \\
\dot{\Xi} \\
\dot{0}\end{array}$ \\
\hline Internet banking has low maintenance costs & 2.4 & 17.1 & 9.8 & 34.1 & 36.6 & 2.15 & 1.17 \\
\hline Internet banking has attracted more retail depositors & 0 & 9.8 & 19.5 & 39 & 31.7 & 2.07 & 0.96 \\
\hline Internet banking has attracted cooperate depositors & 4.9 & 19.5 & 17.1 & 29.3 & 29.3 & 2.41 & 1.25 \\
\hline $\begin{array}{l}\text { Internet banking has attracted more deposits thus } \\
\text { improving financial performance }\end{array}$ & 0 & 22 & 12.2 & 34.1 & 31.7 & 2.24 & 1.13 \\
\hline Use of internet has led to more bank innovations & 0 & 14.6 & 4.9 & 24.4 & 56.1 & 1.78 & 1.08 \\
\hline
\end{tabular}

Table 3 provided presentation showing majority of the respondents agreed that internet banking has low maintenance cost shown by mean scores of 2.15 , internet banking has attracted more retail depositors as shown by mean scores of 2.07 and internet banking has attracted cooperate depositors as shown by mean scores of 2.41, while they also agreed that internet banking has attracted more deposits thus improving financial performance the as shown by mean scores of 2.24 and that use of internet banking has led to more bank innovation shown by mean scores of 1.78 .

\section{Banc Assurance}

Table 4: Response of the Employees in Regards to Banc Assurance

\begin{tabular}{|c|c|c|c|c|c|c|c|}
\hline Statement & 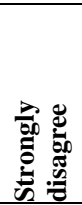 & 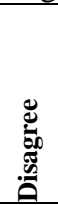 & 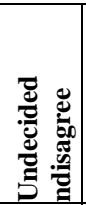 & 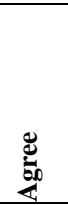 & 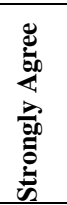 & $\stackrel{\Xi}{\Xi}$ & $\stackrel{\vec{D}}{\dot{D}}$ \\
\hline $\begin{array}{l}\text { Banc assurance has led to the sale of whole } \\
\text { range of financial services }\end{array}$ & 0 & 4.9 & 7.3 & 51.2 & 36.6 & 1.8 & 0.78 \\
\hline $\begin{array}{l}\text { Banc assurance works towards the provision of } \\
\text { integrated financial service }\end{array}$ & 0 & 7.3 & 9.8 & 56.1 & 26.8 & 1.98 & 0.82 \\
\hline $\begin{array}{l}\text { Banc assurance enables bank to tap into a huge } \\
\text { customer base } \\
\text { Banc assurance has made banks to obtain } \\
\text { additional capital }\end{array}$ & 0 & 9.8 & 4.1 & 61 & 24.4 & 2.0 & 0.84 \\
\hline $\begin{array}{l}\text { Banc assurance has enabled customers to carry } \\
\text { out many transactions under one roof }\end{array}$ & 0 & 22 & 2.4 & 26.8 & 48.8 & 1.98 & 1.19 \\
\hline
\end{tabular}

Table 4 provided presentation showing majority of the respondents agreed that banc assurance has led to the sale of whole range of financial services shown by mean scores of 1.8 , banc assurance works towards provision of integrated financial system as shown by mean scores of 1.98 and banc assurance has enabled banks 
to tap into a huge customer base as shown by mean scores of 2.0, while they also agreed that banc assurance has made banks to obtain additional capital as shown by mean scores of 1.73 and that use of banc assurance has enabled customers to carry out many transactions under one roof shown by mean scores of 1.98 .

\section{Financial Performance}

Table 5: Response of the Employees in Regards to Financial Performance

\begin{tabular}{|c|c|c|c|c|c|c|c|}
\hline Statement & 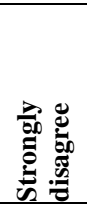 & 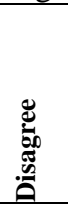 & 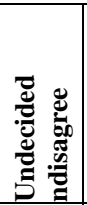 & 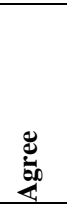 & 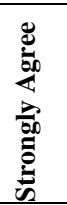 & 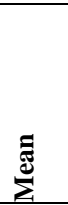 & 它 \\
\hline $\begin{array}{l}\text { Product innovation has greatly improved } \\
\text { banks financial performance }\end{array}$ & 0 & 2.4 & 4.9 & 58.5 & 34.1 & 1.76 & 0.66 \\
\hline $\begin{array}{l}\text { Banks should investigate ways of reducing } \\
\text { innovation challenges }\end{array}$ & 0 & 9.8 & 9.8 & 36.6 & 43.9 & 1.85 & 0.96 \\
\hline $\begin{array}{l}\text { Technological factors greatly influence } \\
\text { commercial banks financial performance } \\
\text { Innovation has improved effectiveness in }\end{array}$ & 0 & 14.6 & 2.4 & 43.9 & 39 & 1.93 & 1.01 \\
\hline $\begin{array}{l}\text { banks hence financial performance } \\
\text { Innovation has led to cost reduction }\end{array}$ & & & & & 56.1 & 1.63 & 0.92 \\
\hline enriching financial performance & 2.4 & 0 & 12.1 & 85.4 & 0 & 2.2 & 0.56 \\
\hline $\begin{array}{l}\text { Employees knowledge on innovation } \\
\text { influence financial performance of your } \\
\text { bank }\end{array}$ & 2.4 & 12.2 & 14.6 & 31.7 & 39 & 2.07 & 1.12 \\
\hline Innovation has led to increase in turnover & 2.4 & 12.2 & 14.6 & 31.7 & 39 & 2.07 & 1.13 \\
\hline
\end{tabular}

Table 5 provided presentation showing majority of the respondents agreed that product innovation has greatly improved banks financial performance shown by mean scores of 1.8, banks should investigate ways of reducing challenges facing innovation as shown by mean scores of 1.85 and Technological factors greatly influence commercial banks financial performance as shown by mean scores of 1.93 , while they also agreed that Innovation has improved effectiveness in banks hence financial performance as shown by mean scores of 1.63 and that Innovation has led to cost reduction enriching financial performance shown by mean scores of 2.2. Majority of the respondents also agree that Employees knowledge on innovation influence financial performance banks as shown by a mean score of 2.07 and they agree that Innovation has led to increase in turnover as depicted by a mean score of 2.07 .

\section{Inferential Analysis}

Inferential analysis is utilized in this study to assess the effects of innovation on financial performance of commercial banks in Nakuru town, Kenya. The inferential statistics analysis aimed to reach conclusions that extend beyond the immediate data alone between the independent variables in this study. The study conducted inferential analysis to establish the relationship between the independent variables and the dependent variable of which involved a coefficient of determination and a multiple regression analysis. The independent variables in this study included mobile banking, agent banking, internet banking and banc assurance, while the dependent variable was financial performance of commercial banks. The study utilized weighted averages to determine the financial performance.

Table 6: Model Summary

\begin{tabular}{|l|l|l|l|l|}
\hline Model & R & R Square & Adjusted R Square & Std. Error of the Estimate \\
\hline 1 & .83 & .692 & .60 & .04 \\
\hline
\end{tabular}

a. Predictors: (Constant), mobile banking, agent banking, internet banking and banc assurance. Coefficient of determination explains the extent to which changes in the dependent variable can be explained by the change in the independent variables or the percentage of variation in the dependent variable (commercial banks financial performance) that is explained by all the four independent variables. The four independent variables that were studied, explain $69.2 \%$ of the financial performance as represented by the $\mathrm{R}^{2}$. This therefore means the four independent variables contribute about $69.2 \%$ to the financial performance while other factors not studied in this research contribute $30.8 \%$.

Multiple linear regression

Table 7: Linear Regression

\begin{tabular}{|l|l|l|l|l|l|}
\hline Variables & Unstandardized & Coefficients & $\begin{array}{l}\text { Standardized } \\
\text { Coefficients }(\square)\end{array}$ & $\mathbf{T}$ & Sig. \\
\cline { 2 - 5 } & $(\square)$ & Std. Error & \\
\hline
\end{tabular}


Influence of Innovation on The Performance of Commercial Banks in Nakuru Central Business...

\begin{tabular}{|l|l|l|l|l|l|}
\hline (Constant) & 1.02 & 0.36 & & 0.92 & 0.007 \\
\hline Mobile banking & 0.09 & 0.14 & 0.15 & 1.08 & 0.019 \\
\hline Agent banking & 0.12 & 0.11 & 0.02 & 1.97 & 0.014 \\
\hline Internet banking & 0.42 & 0.12 & 0.16 & 1.92 & 0.015 \\
\hline Banc assurance & 0.36 & 0.05 & 0.05 & 1.96 & 0.017 \\
\hline
\end{tabular}

The data used for this logistic regression analysis was collected from employees of commercial banks in Nakuru town. The explanatory variables that were used in this study were mobile banking, agent banking, internet banking and banc assurance. Table 7 shows the coefficients on the influence of the individual independent variables on the dependent variable. The Beta coefficients indicate the extent to which financial performance changes due to a unit change in the independent variable. The positive Beta coefficients indicate that a unit change in the independent variable leads to a positive change in financial performance. The researcher conducted a multiple regression analysis so as to determine the relationship between the commercial banks financial performance and the four variables. Regression model is used here to describe how the mean of the dependent variable changes with changing conditions. The regression equation is shown below:

$\mathbf{X}_{4}$

$$
\left(\mathbf{Y}=\square_{0}+\square_{1} \mathbf{X}_{1}+\square_{2} \mathbf{X}_{2}+\square_{3} \mathbf{X}_{3}+\square_{4} \mathbf{X}_{4}+\square \text { will be: } \mathbf{Y}=\mathbf{1 . 0 2}+\mathbf{0 . 0 9} \mathbf{X}_{1}+\mathbf{0 . 1 2} \mathbf{X}_{2}+\mathbf{0 . 4 2} \mathbf{X}_{3}+\mathbf{0 . 3 6}\right.
$$

According to the regression equation established, taking all factors (mobile banking, agent banking, internet banking and banc assurance) constant at zero, the commercial banks financial performance will be 1.02. These results infer that mobile banking contributes more to commercial banks financial performance, followed by agent banking, then internet banking, while banc assurance contributes the least to commercial banks financial performance.

\section{Hypothesis Testing}

Table 7 illustrates that P-Value for the four financial innovations. For mobile banking the $\mathrm{P}$ value is 0.019 . This being less than 0.05 suggests that there is enough evidence to support the alternative hypothesis ( $\beta 1$ $\neq 0$ ) that mobile banking has an effect on financial performance at $5 \%$ level of significance. The $p$ value for agent banking is 0.014 at $5 \%$ level of significance therefore we reject the null hypothesis and conclude that agent banking has a significant effect on performance of commercial banks. With regard to internet banking the $\mathrm{p}$ value was 0.015 at $5 \%$ level of significance; since it is less than 0.05 we reject the null hypothesis and conclude that internet banking has a significant effect on performance of commercial banks. The $p$ value for banc assurance is 0.017 , this is less than 0.05 therefore we accept the alternative hypothesis and conclude that banc assurance significantly influences performance of commercial banks.

\section{Recommendations}

Based on the findings of the study, it can be concluded that bank innovations influence financial performance of commercial banks in Kenya positively. The adoption of innovations by commercial banks has a high potential of improving financial performance and hence better returns to the shareholders. The versatility of innovations has made their adoption rate to be high among both the banks and their customers. It could have been challenging if the adoption was only with either the banks or the customers. Banks in Kenya have continued to perform well even when other sectors of the economy show lagged performance. This can be explained by the use of innovations which have enabled banks to start making income away from traditional sources like interest, trade and asset financing. Banks have been able to make more commission income from transactions done on innovation channels like; mobile phones, agents, internet and banc assurance.

Since technological innovation is aggressively and continuously adopted in Kenya, the government should provide incentives for research and development to research scientists who would continue to invest their time and skills in discovering more bank innovations. It is recommended that the government also pursues a strategy to provide incentives for technology transfer from more developed economies in order to promote the adoption of world class innovations. The ICT regulator should regulate partnerships between the banks and technology operators to ensure that there is fair play. The bank should not exploit the technology users buy overcharging. Information and communication technology (ICT) professionals should invest their time, effort and resources towards innovations. This will mean more income for the professionals if the innovations become successful. In Kenya there are some citizens who are still unbanked due to poor access to financial services. ICT professionals should explore ways of providing innovative solutions for reaching the unbanked.

The study having concentrated all efforts in Nakuru town in Kenya did not focus on other areas like Eldoret, Kisumu, and Mombasa among others which command a big chunk of the Kenyan economy. The study therefore should be conducted in those areas so as to provide a good comparative base and also bring out the right conclusions. Furthermore, related topics to this study like mobile technology safety, role of innovation in 
fighting money laundering, effects of banks technology in growth of the economy and how innovation systems have led to expansion of businesses in Kenya should be studied further. A more detailed study can be conducted to establish whether the adoption of financial innovations contributed to financial deepening in Kenya.

\section{References}

[1]. Abishua, D. A. (2010). Strategic Responses used by Equity Bank to Compete in the Kenyan Banking Industry. Social Science Research Network.

[2]. Aboelmaged, M.G., \& Gebba,T. R. (2013). Mobile Banking Adoption: An Examination of Technology Acceptance Model and Theory of Planned Behavior. International Journal of Business Research and Development, 35-50.

[3]. Acharya, R.N., \& Kagan, A.(2004). Commercial B2B Web site attributes within the perishable sector. Journal of Internet Commerce, 3(4):79-91.

[4]. Acharya, V, \& Subramanian, K. V. (2009). Bankruptcy codes and innovation. Review of Financial Studies, 22, 4949-4988.

[5]. Agarwal. R., \& Prasad, J. (1999). M-Banking to the Un-Banked. Retrieved May 26, 2010, from Frost and Sullivan.

[6]. Agboola, A. (2006). Mobilization of finance for rural housing technology, DOI 10.1002/jid. 40100304407.

[7]. Aduda, J., \& Kingoo, N. (2012). The Relationship between Electronic Banking and Financial Performance among Commercial Banks in Kenya. Journal of Finance and Investment Analysis, 1(3), 99-118.

[8]. Alhajri, J.K., \& Allam, M. H. (2008).The impact of information technology on improving banking performance matrix: Jordanian banks as case study. European, Mediterranean \& Middle Eastern Conference on Information Systems 2010. April 12-13 2010, Abu Dhabi, UAE.

[9]. Baregheh, A., Rowley, J., \& Sambrook, S.(2009). Towards a multidisciplinary definition of Innovation. Management decision, 1323-1339.

[10]. Batiz-Lazo, B., \& Woldesenbet, K. (2006). The dynamics of product and process innovation in UK banking. International Journal of Financial Services Management, 1 (4), 400-421.

[11]. Bagozzi, R. P., Davis, F. D., \& Warshaw, P. R. (1992). 'Development and Test of a Theory of Technological Learning and Usage', Human Relations.Vol.45, No.7.

[12]. Barnes, S.J. (2003). Enterprise mobility: Concepts and examples. International Journal of Mobile Communications, 1( 4), $341-359$.

[13]. Bartezzaghi, B., Bátiz-Lazo, B., \& Reid, R. J. (2011). The development of cash dispensing technology in the UK. IEEE Annals of the History of Computing.

[14]. Baregheh, A., Rowley, J., \& Sambrook, S. (2009). Towards a multidisciplinary definition of Innovation. Management decision, 1323-1339.

[15]. Berger, A. N. (2003). "The Economic Effects of Technological Progress: Evidence from the Banking Industry", Journal of Money, Credit and Banking, Vol. 35 No. 2.

[16]. Bradley, L., \& Stewart, K. (2003). Delphi study of internet banking. MCB UP Limited pp. $272-281$.

[17]. Bhattacharya, S,. \& Thakor, A. (1993). 'Contemporary Banking Theory,', Journal of Financial Intermediation 3, $2-50$.

[18]. Bryman \& Bell. (2003). is the resource-based 'view' a useful perspective for strategic management research? The Academy of Management Review, 26(1), 22-40.

[19]. Blumberg, B., Cooper, D. R., \& Schindler, P. S. (2008). Business Research Methods (2nd ed.). London: Mc Graw-Hill.

[20]. Camillo, M. (2008). Internet banking and online trading E-government service maturity and development: cultural, organizational and technological perspectives.

[21]. Campbell, R. H. ( 2012). Report of the Editor of the journal of Finance.

[22]. CBK. (2007). Central Bank of Kenya Directory of Commercial Banks and Mortgage Finance Companies, Kenya. Retrieved on Thursday, 18th August, 2011at http://www.centralbank.go.ke/downloads/bsd/Commercial\%20Banks\%20 Dire ctrory\%20\%2031\%20December\%202010.pdf

[23]. Ceylan, O., \& Emre, O. (2011). The impact of internet-banking on bank profitability- The case of Turkey. Oxford Business \& Economics Conference Program ISBN : 978-0-9742114-7-3

[24]. Chaia, K., Patrick, Y., \& Lai, S., K. (2003). An empirical investigation of the determinants of users of internet banking. Journal of IB and Commerce 11 (3), Available athttp://www.arraydev.com/commerce/jibc/

[25]. Chan, K. F., Hung- Chi, L., \& Wen - Chin, L. (2013). An Evaluation of Key Factors for Bancassurance Success. International Journal of Application and Innovation in Engineering and Management, 2 (12), 190-198.

[26]. Cohen, J. (2011). Statistical Power Analysis for the Behavioral Sciences, 2nd Edition.Commercial Banks", Emerging Issues Series, Supervision and Regulation.

[27]. Clerk, J. (1995). before you give new products the green light... ABA Banking journal, 13-17.

[28]. Cooper, D \& Emory, C. (1996). Business Research Methods. Chicago.

[29]. Coleman J. (2011). Business Research: A Practical Guide for Undergraduate and Postgraduate Students. Chicago: Palgrave Macmillan.

[30]. Collis, J., \& Hussey, R. (2003). Business Research: A Practical Guide for Undergraduate and Postgraduate Students, Palgrave Macmillan, Basingstoke.

[31]. Davis, F.D. (1986). User acceptance of information technology: system characteristics, user perceptions and behavioural impacts. International Journal of Man-Machine Studies, 38(3), 475-487.

[32]. Dew,K. (2007). Innovation Segregation by two Australian merchant banks: A private alternative to the financial patent for protecting financial innovations and informing investors. Working Paper available at http://ssrn.com/abstract=995960, accessed on 22 September 2011

[33]. Davis, M. (2009). Access to Finance Chapter 2, Handbook of Development Economics, Volume 5, DaniRodrikand Mark Rosenzweig, eds.

[34]. Delone, C., \& Mclenan, S. (1992). "Non interest Income and Financial Performance at U.S. Commercial Banks", Emerging Issues Series, Supervision and Regulation Department, Federal Reserve Bank of Chicago.

[35]. DeYoung, R., Lang, W., \& Nolle, D. E. (2006). "How the Internet Affects Output and efficiency. Performance at Community Banks", Journal of Banking and Finance.

[36]. Dishaw, M.T., \& Strong, D.M. (1999). Extending the technology acceptance model with task technology fit constructs. Information \& Management, 36(1), 9-21. Working Paper. Rutgers University

[37]. Freedman, C. (2000). Monetary Policy Implementation: Past, Present and Future-' Will Electronic Money Lead to the Eventual Demise of Central Banking?' International Finance, Vol.3, No.2, pp. 211-227.

[38]. Freixas, X., \& Rochet, J.C. (1998). Microeconomics of banking, MIT Press. 
[39]. Friedman, B. (1999). The Future of Monetary Policy: The Central Bank as an Army with Only a Signal Corps? International Finance, Vol.2, No.3, pp.321-338.

[40]. Furst, K., Lang, W. W. and Nolle, D. E. (2000). “Who offers Internet Banking?” Quarterly Journal, Office of the Comptroller of the Currency, Vol. 19 No. 2, June, pp. 27-46.

[41]. Federal Reserve Bank of Chicago. (2000). Journal, Office of the Comptroller of the Currency, Vol. 19 No. 2, June, pp. 27-46.

[42]. Gardashew, D., Sadgina, I. M., \& Zumwalt, J. K. (2002). The Changing Relationship between Ratings and Bank Soundness during the Indonesian Banking Crisis, journal of Quantitative Finance and Accounting, 19, 247 -260.

[43]. Goetzmann, W. N. (2009). Financing Civilization. mimeo, Yale University.

[44]. Good, H., \& Thompson. (2007). Can theory knowledge and application lead to competitive advantage. Marketing intelligence and planning, 232-240 MIS Quarterly, 19(2) 213-236

[45]. Glen, I. M., \& Zumwalt, J. K. (2002). The Changing Relationship between CAME Ratings and Bank Soundness during the Indonesian Banking Crisis, journal of Quantitative Finance and Accounting, 19, 247 -260.

[46]. Hamilton, R., Jenkinson, N., \& Penalver, A. (2007). Innovation and Integration in Financial Markets and the Implications for Financial Stability, in C Kent and J Lawson (eds), The Structure and Resilience of the Financial System, Proceedings of a Conference, Reserve Bank of Australia Sydney, pp 226-250.

[47]. Hirtle, B. J., \& Stiroh, K.J. (2007). The return to retail and the performance of U.S. banks. Journal of Banking and Finance, 31, $1101-1133$

[48]. Ivatury, G., \& Ignacio M. (2008). “The Early Experience with Branchless Banking.” Focus Note 46. Washington, D.C.: CGAP.

[49]. Jushua, A. (2010). Technological innovations and banking: An evaluation of customer's perceptions. Academic leadership online journal, 8(4).

[50]. Junglas, I.A., \& Watson, R.T. (2006).The u-constructs: Four Information Drives. Communications of the Association for Information Systems, 17, 569-592

[51]. Jongeneel, O.C.W. (2011). Bancassurance: Stale of Staunch? A Pan- European country analysis. Unpublished Msc. Economics \& Business Thesis, Erasmus University.

[52]. Jurgen, A. (2010). Technological innovations and banking: An evaluation of customers perceptions. Academic leadership online journal, 8(4)

[53]. Kagan, A., Acharya, R. N., Rao, L. S., \& Kodepaka, V. (2005). Doe internet banking affect the performance of community banks? Selected Paper prepared for presentation at the American Agricultural Economics Association Annual Meeting, Providence, Rhode Island July 24-27, 2005.

[54]. Karjaluoto, H., Mattila, M., \& Pento, T. (2002). Factors underlying attitude formation towards online banking in Finland. International Journal of Bank Marketing, 20 (6), 261- 272.

[55]. Kombo, D.K., \& Tromp, D.L.A. (2009). Proposal and Thesis Writing: An Introduction. Paulines Publications Africa, Don Bosco Printing Press, Nairobi Kenya.

[56]. Kohen, M., Hopkins, D., \& Lee, J. (2008).Financial Education: A Bridge between Branchless Banking and Low-income Clients.Washington DC: Microfinance Opportunities.

[57]. Kumar, M. (2008). Best Practices in Bancassurance. Journal of Bancassurance, 73, 30- 45, retrieved from http://www.bcworldwide.com

[58]. Konthari, C.R. (2009). Research Methodology techniques. International Journal of Bank Marketing, 190-201.

[59]. Lawrence, J.W. (2010). Technological Change Financial innovation and Financial Regulation in the US, cited fromciteseerx.ist.psu.edu/viewdoc/download?doi=10.1.1.155.1655

[60]. Lerner, J. (2002). Where does State Street lead? A first look at finance patents, 1971-2000. Journal of Finance, 57, 901-930

[61]. Lyon . (2007). Encyclopaedia of Survey Research Methods Vol. 1 \& 2. Sage Publications, Los Angeles, United States of America.

[62]. Mahajan \& Peterson. (1985). Innovation diffusion model.

[63]. Magutu, R. C. (2009). Financial Innovation and the Management and Regulation of Financial Institutions, Journal of Banking and Finance (July), 461-482.

[64]. Mabrouk, A., \& Mamoghli, C. (2010). Dynamic of financial innovation and performance of banking firms: Context of an emerging banking industry. International Research Journal of Finance and Economics, 5, 2010

[65]. Mahdi, S., \& Mehrdad, A. (2010). E-banking in emerging economy: Empirical evidence of Iran. International Journal of Economics and Finance, 2(1), 201- 209

[66]. Malmendier, U. (2009). Law and finance at the origin. Journal of Economic Literature, 47, 1076-1108.

[67]. Mc Andrews J. (2002). Journal of monetary economics, why banks are holding so much reserve.

[68]. Mcmillan \& Schumaker. (2001). Non-enforceable implementation of enterprise mobilization: and exploratory study of the critical success factors, Industrial Management \& Data Systems, 105(6), 786-814.

[69]. Moon, J. \& Kim, Y. (2000). Extending the TAM for a World-Wide-Web Context, Journal of Information and Management, 38 (4), 217-230.

[70]. Mugenda, M.O (2003). Research Methods: Acts Press, Nairobi.

[71]. Mukherjee, A., \& Nath, P. (2003). A model trust in online relationship banking.International Journal of Bank new information technologies?Decision Sciences, 30,361-391.November. Performance at Community Banks", Journal of Banking and Finance. (Forthcoming)

[72]. Nader, A. (2011). The effect of banking expansion on profit efficiency of Saudi banks. 2nd International Conference on Business and Economic Research (2nd ICBER 2011) Proceeding 269.

[73]. Narayan,R.K \& Smyth, R. (2004). International Journal of Applied economics, 221 F Supp 2d 552

[74]. Ngechu, S.(2004). Descriptive Research Design nalele University Maritime Constanta, 51(14), 237-240.

[75]. Nyakundi, D.O.(2013) .Management Perception of Bankassurance as Risk Mitigation Strategy at Equity Bank. Unpublished MBA project, University of Nairobi.

[76]. Nofie, P.L. (2011). The involution of Electronic Banking Indonesia

[77]. Okiro, K., \& Ndungu, J. (2013). The impact of mobile and internet Banking on financial performance of financial institutions in Kenya. published MBA project, University of Nairobi.

[78]. Omondi, R.P. (2013). Determinants of Adoption of Bancassurance by Commercial Banks in Kenya. Unpublished MBA project, University of Nairobi.

[79]. Perry, M., O'Hara, K., Sellen, A., Brown, B., \& Harper, R. (2001). Dealing with mobility: Understanding access anytime, anywhere. ACM Transactions on Computer-Human Interaction, 8(4), 323-347.

[80]. Porter, M. E. (1992). Capital disadvantage: America's failing capital investment system. Harvard Business Review, 70, 65-82. 
[81]. Porter, M.E. (1985). Competitive Advantage. New York, USA: Free Press. Ch.1 pp 11-15

[82]. Porteous, D. (2006). The Enabling Environment for Mobile Banking in Africa, London: DFID.http://www.bankablefrontier.com/assets/ee.mobil.ban king.report.v3.1.pdf.

[83]. Prager, R. (2001). The effect of ATM surcharges on Small banking organizations. Review of Industrial Organization 18, 161173.

[84]. Pooja, M., \& Balwinder, S. (2009).The impact of internet banking on bank performance and risk: The Indian experience. Eurasian Journal of Business and Economics

[85]. Rogers, E. (1983). Diffusion of Innovations, 3rd edition. New York, NY: The Free Press.

[86]. Rogers, E.M. (2005). Diffusion Innovation (5thEd.) New York: the Free Press.

[87]. Roberts, P., \& Amit, R. (2003). The dynamics of innovative activity and competitive advantage: The case of Australian retail banking, 1981 to 1995 . Organization Science, 14 (2), 107-122.

[88]. Romero, 1., \& Martine- Roman, J .A.(2012). Self employment and innovation, exploring the determination of innovation behavior in small business.

[89]. Servick . (2004). Cell Phone Banking Adoption in South Africa. Business and Economic Research, 1(1).

[90]. Santomero, A.M, \& Seater J.J. (1986). Alternative Monies and the demand for Media of Exchange, Journal of Money, Credit and Banking, Vol.28, pp. 942-960.

[91]. Schumpeter, J. A.(1934). The Theory of Economic Development. Cambridge: Harvard University Press.

[92]. Solans, E. D. (2003). Financial innovation and monetary policy. Excerpts of speech delivered at the 38th SEACEN Governors Conference and 22nd Meeting of the SEACEN Board of Governors on "Structural Change and Growth Prospects in Asia Challenges to Central Banking", Manila (13 February 2003). http://host.uniroma3.it/eventi/wolpertinger2009/37.pdf

[93]. Sufian, P \& Perman, J . (2009). Specialisation and other determinants of profitability of financial institutions 18, 161-173.

[94]. Tarkka, J.(2002). The Market for Electronic Cash Cards, Journal of Money, Credit and Banking, Vol.34, pp.299-314.

[95]. Tushman, M,. \& Nadler, D. (1986). organizing for innovation. California management review, 28(3), 74-92.

[96]. Republic of Kenya, (2008). A globally competitive and prosperous Kenya. First Medium Term Plan 2008-2012, Ministry of State for Planning, National Development and Vision 2030.

[97]. Worthington, S., \& Welch, P. (2011). Banking without the banks. International Journal of Bank Marketing, 190-201.

[98]. Wuldsonbet, D.(2006). Country resource environments, firm capabilities and corporate diversification strategies. Journal of Management Studies, 42: 161-171.

[99]. Zigurs, I., \& Buckland, B.K. (1998). A theory of task-technology fit and group support system effectiveness. MIS Quarterly, 22(3), 313-334.

[100]. Zigurs, I., Buckland, B.K., Connolly, J.R., \& Wilson, E.V. (1999). A test of task technology fit theory for group support systems. Database for Advances in Information Systems, 30(34), 34-50.

[101]. Zikmund, G.W., Babin, B.J., Carr, C.J. \& Griffin, M.(2010). Business Research Methods $\quad 8^{\text {th }} \quad$ ed. $\quad$ South-Western, Cengage Learning. 